\title{
Modernism and (Italian) Hermeticism in Contemporary Albanian Poetry: The Poetry of Zef Zorba
}

\author{
Dr. Bavjola Shatro (Gami) \\ Aleksandër Moisiu University \\ Email: shatro.uamd.edu@gmail.com
}

\section{Doi:10.5901/jesr.2014.v4n6p477}

\section{Abstract}

This article focuses on the poetry of Zef Zorba which is a contemporary Albanian poet and one of the representatives of Albanian literature that was written under the extreme communist censorship in the period 1945-1990. Zef Zorba is considered as spokesperson of modernism and hermeticism in Albanian poetry. He is a key representative of a phenomenon that scholars in Albanian Studies refer to as "literature of the drawer" since this is a literature that was written secretly during communism and was never made public under any circumstance due to the extreme censorship over literature and the brutal punishments of writers. The article designates a comparative approach between Zorba's poetry and the poetry of the eminent Italian poet Giuseppe Ungaretti. This comparative approach could contribute to further research in the theoretical realm i.e. the history of Albanian literature and world poetry during the twentieth century. It could also bring significant help in the didactic aspect because it gives more ground to analysis and synthesis of hermeticist poetry which is known for its obscurity that cause difficulty to students when analyzing it. The method used in this paper is the culturological one and text analysis.

Keywords: Hermeticism, poetry, communism, modernism, motifs.

\section{Introduction}

The complex relationship between literature and ideology in European countries was displayed in a very complex way during the communist regime which kept behind the "iron curtain" half of the continent for almost 50 years. In several East European countries this forced relationship between literature and ideology produced a propagandistic literature, which was essentially different from the pre-WWII literary tradition. Albania is one of the former communist countries of the Bloc where communism ruled undisturbed through extreme forms of punishment and oppression from 1945 until 1991. During the communist regime in Albania there was exercised an extreme surveillance and censure against writers and intellectuals. Persecutions, imprisonments and even executions were common and happened repeatedly particularly from 1945 until the end of the 1975. However violence continued even after the mid 1970s and "[...] poet Havzi Nela was publically hanged at the central square of a northern town in Albania on pure ideological basis as late as 1988."1

In order to survive writers choose either (a) to escape from Albania during the early years of the establishment of the regime; (b) to surrender to socialist realism and the State politics; or (c) to be willingly and completely marginalized from the literary process in the country. The third group of writers those who chose to remain anonymous throughout the regime wrote the so called "literature from the drawer" (Sinani 2011) and Zef Zorba is a key representative of this literature. Zorba chose not to make public his literary work. His poetry and his other contributions in literature weren't even mentioned anywhere in public for almost 50 years. This was the high price that the poet paid in order to guarantee the survival of himself and his family. He has written poetry, literary criticism and has translated several literary and philosophic masterpieces but all this literary contribution remains still in his family's archive. His only book of poetry already published is Buzë të ngrira në gaz (Engl. Lips Frozen in a Smile) and was published in 1993 after the collapse of communism and after the author's death.

Zef Zorba was born in 1920 in Kotorr in Montenegro to an Albanian family2 from Shkodra the biggest and most

\footnotetext{
${ }^{1}$ Bavjola Shatro, "Albanian Literature during the Establishment of the Communist Regime", paper presented in the LiteraryPax Sovietica Conference, University of Sheffield, UK, May 2014.

2 Zef Zorba was the son of Milena Skanjeti- Zorba, the daughter of Andrea Skanjeti, an Italian intellectual who was the President of the Commercial College in Shkodra - a very famous institution at that time- and of a lady that is the icon of the Albanian painting - Sister Tone (Motra Tone). Hence Zef Zorba was the nephew of the eminent Albanian painter known as the Michelangelo of Albania Kolë Idromeno.
} 
important northern city in Albania. Shkodra had been a cultural center during more than 2 millennia and this historical heritage would leave a significant mark on Zorba's life and poetry. After completing the gymnasium in Shkodra in 1941 Zorba left Albania to study at the University of Padua in Italy. He studied Political Science but had to interrupt his education because of World War II. He returned in Albania in 1943 and worked as a banker for few years.

During the period 1945-1946, Zorba worked as director in the Cultural Center in Shkodra and had considerable success because of some important works that were performed under his direction. Ibsen's "The Peoples' Enemy" and the tragedy "Juda Makabe" written by an eminent Albanian poet - the Franciscan priest Gjergj Fishta that was expelled from the History of Albanian literature during 5 decades of communis - gave him a well-deserved reputation in that time. When Zorba chose to perform these challenging works in the theatre he made an intellectual and artistic resistance to the regime that was at its dawn in Albania.

In 1946, Zorba was arrested and imprisoned for 5 years on political charges. The same happened to his wife Teresa who spent herself 5 years in prison. After being released from prison Zorba worked as an accountant in different factories in Shkodra until 1980 when he retired. He never spoke about his poetry and was never publically part of the cultural life of his country.

Zorba was an eminent representative of the Albanian intellectuals at the end of WWII. This is particularly important considering that at that time almost $80 \%$ of the population of the country was illiterate and Albania was a small and -to some extend- still a feudal country (Xhiku 2014). Since communism in Albania considered the intellectuals and writers as representatives of the old regime (Elsie 2001) Zorba - who even had a western culture and education- was almost an inevitable target for the regime's persecutions.

Especially after the establishment of communism Zorba - like many other Albanian intellectuals and writersunderstood that he could not have anything in common with the communist dictatorship or socialist realism. In order not to suffer further imprisonment or worse he chose not to publish anything for almost 5 decades although he continuously wrote in secret. Besides writing poetry his work focused on the translation of poetry and of several well-known philosophers. He translated into Albanian the work of Giuseppe Ungaretti, Salvatore Quazimodo, T. S. Eliot, E. Montale, R. Frost, B. Shaw, L. Pirandello, B. Croce, H.-G. Gadamer etc. His aesthetical concepts have been influenced in part from these authors. Zorba wrote also opera librettos, dramas, studies etc.

His poetic volume Buzë të ngrira në gaz represents a literary enigma because the poet wrote it for 40 years in complete silence. In the afterword of the volume Zorba writes: "... these poems weren't written to be published because even the thought of their publication someday scares me immensely" (Zorba 2010). This statement suggests that the relationship between the poet's life and his poetry is a phenomenon that could reveal much about his literary individuality and about the development of the literary process in communist Albania. Under these circumstances Zorba's poetry was forced to have no reader and was practically defined to be a literary work, which belongs only to the future. The effect of such unusual circumstances on the poems and on the writer represents an issue that deserves thorough analysis but that goes beyond the reach of this article.

\section{Zef Zorba and the Modernist Pattern in Contemporary Albanian Poetry}

Zorba's poetry reflects a natural affinity to the brightest part of the world's literary tradition. Dante's poetic images and artistic sensitivity are often present in his work. However he was also a follower of modernism. Zorba experimented several avant-gardist techniques in his poetry and successfully combined music and verses in poems that are clear modernist pieces (Zorba 2010).

Zorba's poetry is very elliptic; it is a synthetic poetry and is characterized by essentialism at the semantic level and the level of expression. These are features, which define his poetry and draw it near to modernist poetry and especially to hermeticism. As a result, his poetry often appears in the model of aphorisms or miniature since it successfully combines poetic minimalism and highly abstract imagery. Morphological and prosodic means in his poems are carefully chosen. Their function is to accompany and express the inner phenomenology of the lyrical self. This perspective influences the creation of a complex and sophisticated mosaic of perceptions and poetic images.

Another important modernist feature that is often found in the poetry of Zorba is fragmentarity, which Zorba himself calls an essential fragmenarity. This appears to be a constant literary procedure and a purposeful choice that eventually accomplishes a great variety of associations and poetic allusions. Fragmentarity is accompanied by a particular attention towards the tone and the semantic variety of the words and poetic phrases. Zorba uses fragmentarity while he formulates his poetic text in the model of musical parts such as sonata, fugue, tempos, cadenza etc., and also dramaturgical phrases that incorporate the musical elements. 
Among the characteristic literary devices of the poetry of Zef Zorba are also irony and paradox. These figures together with parallelism and personification lead to a typical feature of his poetry which is the semantic division of the title form the content of the poem. The contrast between the titles of the poems and the content is a literary device that underlines the inevitable drama of the lyrical self and leads to a distinguished aesthetical phenomenon of Zorba's poetry: his acute self-irony. This self-irony accomplishes the balance towards pathetism, naivety and enthusiasm that have no place in the world of the lyrical self (Zorba 2010). The privileged place of irony in Zorba's poems is a very important phenomenon in the context of contemporary Albanian poetry because:

\section{"...the irony as a key procedure of modernity and post modernity in general has been a rare and a secondary procedure in Albanian literature and poetry. It never became a characteristic let alone a dominant feature while this was the case of other European literatures. However in the volume by Zef Zorba it is essential...." (Kuçuku 2012)}

Another very important characteristic of Zorba's poetry is also impersonalism which is often expressed in his poetry in a manner that reminds us of T. S. Eliot's work. Still deep personal experiences and impersonalism are usually intertwined in a way that more than reminding us the aesthetics of modernism outlines an artistic model that is typical of Zorba's poetry. In the context of an individual aesthetics it can be maintained that even his verse is a typically nontraditional one. Rhyme gradually disappears in his poetry and the verses are more spontaneous. The poetic phrase is enriched with expressions that are unexpectedly concluded in the middle of the verse. It is here that appears the caesura which is a typical modernist device and is often expressed through the period. Zorba is a poet who had his own aesthetic theory, which was clearly formulated in the Afterword of his volume. This makes him a follower of some key modernist authors in European literature and a rare case in Albanian literature. His literary explanations and arguments represent accomplished theoretical value (Hamiti 2003).

An important aspect of Zorba's poetry which represents a challenge both on the theoretical aspect as well as in the didactic aspect when teaching his poetry in the context of contemporary Albanian poetry is his affinity to (Italian) hermeticism. His contact with the Italian culture even before studying in the University of Padua could have been the cause of the influence of Italian heremticism in his poetry. As it's been rightly maintained by scholars that hermeticism doesn't have the purpose of protecting the poet from open expression of his thoughts and feelings which might cause him harm under the dictatorship (Ndreca 2010). This point of view is supported by the fact that Zorba didn't intend either to publish his poems or to make them public in any way. His affinity to Italian hermeticism could have been a natural approach due to his sophisticated literary taste and to the fact that hermeticism suited his very reserved and discrete nature as a person.

His poetry seems to resemble that of Salvatore Quasimodo in the sense of desperation and mourning that it expresses. Meanwhile it also reminds us of the perspective of Ungaretti when he considered that poetry should develop parallel to the slightest changes of the human soul. Meanwhile the feeling of disillusionment and sadness that one often finds in E. Montale's poetry is part of Zorba's poetry as well. The similarities between Zorba and the Italian hermenticism could be expressed through the words of Gilberto Finzi who maintains that the hermeticist's myth:

\footnotetext{
"...is the myth of the psychological and metaphysical solitude of man in the course of life's struggles and pain; it is the nothingness of the ruins of the human heart [....]. What the critics call the Poetics of the Word is to be found in the perfect technique of a precise language, a language which is closed in itself, which is sophisticated and that is never left loose in the extreme certainty that derives from imaginations that one remembers or recalls ....". (Finzi 2005, translation mine-B.S.)
}

Zorba's poetry is written through a technique which was characteristic of the work of the hermeticists before WWII: he brings rhythm, punctuation and the whole poetic structure under the control of the evocative effect of every single word. Consequently, he is a modernist poet whose poetry is a very compact and sophisticated texture that bears a resemblance to the abstract painting (Lanksch 1992). Although Zorba's poetry aims constantly to synthesize and to formulate the abstract realities it is also a very intimate and personal poetry. (Poems: Merimangë, Zhigu, Robër, Si zogj dallëndysheje etc.) Thus, it is a model of modernity while it also represents a clear sense of lyricism which is present in the literary work of Ungaretti, Montale and Quazimodo in their later years.

However Zorba hasn't walked blindly in the path of the hermeticists. His moderate approach to the hermeticist aesthetics is a purposeful act of poetic conscience because to Zorba it was crucial to focus on the critical analysis of the inner world of the individual. He aimed to meditate on the purely individual worldview, on the circumstances and the condition of being. His poetry is created upon concrete life episodes and personal events that imprinted his life with everlasting memories. Therefore his poems are indeed the parts of a poetic biography of his own life. 
There are scholars who maintain that Zorba's poetic cycles The Last Fugues and Impressions from the Road "[...] are enough to give him a well-deserved place among the modernists of European literature." (Lanksch 1992). These poems have a very natural intertwining of visual images, feelings and re-experiencing of memories. Each part of the poem is titled after a musical part and can be read as a poem of its own. The poems create musical effects which are similar to those of the musical instruments. Especially in these poems we see the lyrical self taking a journey in his memories and also in the collective memory about the condition of man in the world.

Zorba's poetic volume is structured as a typical modernist volume and could be compared to that of Charles Baudelaire. The first poem of Zorba's book is titled Instead of an introduction. This short poem is the heart of the whole volume and represents an Aeschylian image of life: the condition of being always in the edge of destruction. The anxiety and fear of being trapped and of the inevitable fall that is about to happen are present in the two short stanzas of the poem, which operate as independent semantic units but still configure two stages of the awareness of existence. This poem describes much of Zorba's life as well as the human condition in general.

\title{
Instead of an introduction
}

\author{
Dark this pathway. I can't \\ Find the way without your \\ Light. (what pricks me?) \\ At the edge of the precipice, \\ That seduces and isolates \\ Don't you see how I sway?
}

Scholars have maintained that further analysis on the work of Zef Zorba could help "[...] to understand better the fragmented and somehow distorted process of Albanian literature" (Kadare 2010) but it would also help to understand several phenomena that characterized the development of European literature during the twentieth century.

\section{Giuseppe Ungaretti and Zef Zorba; Hermeticism and Insight}

Ungaretti is one of the most influential figures in twentieth-century European poetry, and is practically the most important poet in Italian literature. He is well known for his attempts to write poetry of high condensation and accomplished images that were free of lyricism or other rhetorical excesses. It's widely maintained that after his hermeticist period Ungaretti approached more traditional forms of Italian poetry and passed from innovation and experimentation to more classical forms of poetry. Ungaretti's influence in Italian poetry and beyond Italian literature - in Zorba's poetry in the given caseis surely a fact worthy of further investigation since it is widely accepted now that:

"Ungaretti has been the most penetrating, influential, and-if I may put it this way-insinuating master of poetry Italy has had in this century. This seems more a statement of fact than a mere opinion of his readers." (Anceschi, 1974)

Ungaretti's poetry is highly personal and intimate while it focuses on the logic of time and the alienation of the human nature in the world. Allen Mandelbaum's states that:

\footnotetext{
"Ungaretti purged the language of all that was but ornament, of all that was too approximate for the precise tension of his line. Through force of tone and sentiment, and a syntax stripped to its essential sinews, he compelled words to their primal power." (Mandelbaum 1975)
}

The comparison between Ungaretti's poetry and the poetry of Zef Zorba contributes to further research in two aspects: (a) it could shed light on the aesthetics of Zorba as a modernist poet who wrote under communist censorship and therefore offer a wider understanding of the literary process in Albania during the second half of the twentieth century; (b) it could display aspects of Ungaretti's aesthetics and influence on other poets of the twentieth century and show the legacy of hermeticism in other European literatures. When speaking about Ungaretti's aesthetics we share the perspective of previous scholars who maintain that:

"Any attempt to examine Ungaretti's aesthetics is bound to pose a large number of problems, partly because of the complexity of his lyrical vision and partly because his poetic manner is overlaid by an equally complex network of borrowed literary features drawn mainly from Petrarchan sources. (Jones 1977) 
This relationship to the heritage of Italian poetry and the complexity of the lyrical visions of Ungaretti are often found in Zorba's poetry too and stress the same aspects of despair, disaster, survival, tenderness and deep inner experiences of the lyrical self. Besides the poetry of these authors have similarities at the level of language too since they both break the rules of grammar and semantics and aim to find a new and fresh meaning of the words:

"When I read a "hermetic" poet like Ungaretti, I often get the sense that his language has been pared by doubt, as if he felt that breaking the semantic threads of grammar would clear the way for a renewed sense of meaning in his doubting heart and mind. Or maybe his stitched-together fragments represent vestiges of faith or confidence in life's meaningfulness." (Andrew 2002)

T. S. Eliot considered Ungaretti to be one of the very few authentic poets of his generation and an admirable representative of Italian poetry in Europe and in America. This surely reminds us that in Ungaretti's volumes:

"...every poem is open, and not closed, to all the winds of the spirit and the world; and the poetry of Ungaretti has always communicated to me a freshness, a free air, of boundless light and the persuasion of a voice both moved and moving ... so sober, so precise with his phrases, so concise amidst the silences of white spaces." (quoted in Atlas 1969)

A comparison between two poems one by Ungaretti and the other by Zorba could enlighten some of the aspects of the similarities and the influence of Ungaretti in Zorba's work as well as the individuality and the personal perspective of hermeticism and lyrics in the work of the Albanian poet. The following poem is the last part of the long poem: Impressions of roads by Zef Zorba.

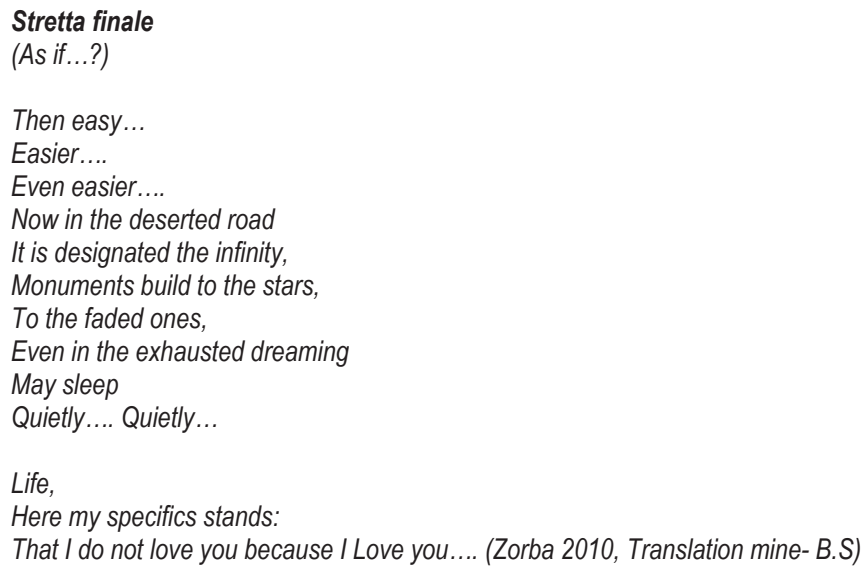

Resemblance between this poem and the entire cycle Impression of the road by Zef Zorba with Ungaretti's Cantos in the cycle La morte mediata (Canto primo until Canto sesto) are not hard to identify. Life and death, memory, impressions of the past and the clear conscience about the end and the swaying at the edge of everything is clearly seen. The musical reference and the strong lyrical meditation as well as the organization of verses with particular attention for the evocative effect of the words are clearly obvious. The sudden appearance of beauty and of inspiration and everything that makes the fear of death and sadness perish is also present in both their poems:

\section{Canto Sesto}

1932

O bella preda,

Voce notturna,

Le tue movenze

Fomentano la febbre.

Solo tu, memoria demente, La liberta' potevi catturare. 
Sulla tua carne inaferrabile

E vacillante dentro specchi torpidi,

Quail delitti, sogno,

Non mi insegnasti a consumare?

Con voi, fantasmi, non ho mai ritegno,

E dei vostri rimorsi o pieno il cuore

Quando fa giorno. (Ungaretti 2009)

The comparison displays also important differences in the aesthetics of these poets such as the fact that in Zorba's poetry one doesn't find a direct reference to historical facts while we know that the testimonial element in Ungaretti's work during the second decade of the twentieth century was obvious and crucial. But on the other hand Ungaretti is well-known for his relationship with silence which is shown even in the blank spaces of the pages of his books. This relationship led him to discover the virtuosity of the poetic word (Ungaretti 2009). Ungaretti's poetry often accomplishes the configuration of a painful feeling that defines the human condition of survival. The process of surviving is an exhausting route that continues day after day (Ibid.). The volume Vita d'un uomo determined the consolidated relationship between tradition, past and memory in Ungharetti's poetry. There are reasons to maintain that the same relationship as well as the natural affinity to silence is fully embraced by Zorba too and practically every poetic cycle of his volume could serve as an illustration for this interpretation.

A comparison between these two poets could be especially helpful to: (a) a more effective teaching of modern poetry in the course of the literary process in world literature; (b) it would be helpful to establish patterns of comparison that are crucial to qualitative research in literature and particularly when trying to understand literary influences between writers that belong to different social and cultural contexts; (c) this perspective allows fruitful synthesis on the combination of biographical, structural, and culturological approaches to the poetry of Zorba as well as a broader perspective on the way Ungaretti influenced poets who kept writing according to his aesthetics even few decades after hermeticism had already changed its course and characteristics in world literature.

\section{Conclusion}

The present cultural and social context in a globalizing world suggests new approaches to national literatures and to world literature. After 50 years of communist regime and censorship Albania - on of the former communist countries of the Eastern Bloc- is still trying to find the key representatives of literature that refused to write in conformity with socialist realism. Hence Albanian literature is still attempting to bring its significant voice into the worldwide academic discussion about the relationship between literature and power, politics and ideology during the twentieth century.

Zef Zorba is one of the representative authors of what is called "literature from the drawers" which refers to a literary product that was written but never made public during the communist dictatorship. This poet is a modernist and an exponent of avant-gardism in Albanian contemporary literature.

His poetry shows notable similarities with Italian hermeticist poets and a comparative approach with the representative Italian poet Giuseppe Ungaretti could help to shed life on the literary phenomenon of hermeticism as well as on other aspect of the literary process during the twentieth century. This comparative approach between these writers is to be preceded by an analysis of the relationship between Zorba's poetry with modernism and his relationship to hermeticism as well.

Considering that poetry and especially hermetic poetry is a constant challenge to the teaching of literature there have been efforts to highlight some of the elements that support further analysis and more convincing interpretation of these poets' work. This analysis was made while taking into account the didactic aspect of literary interpretation as well as the constant academic debates related to twentieth century literature.

\section{References}

Anceschi, Luciano. (1992). "Ungaretti 1919-1927: The Word 'Broken into Pauses'." Forum Italicum. 25-35.

Atlas, James. (1969). "Giseppe Ungaretti; silouhette". \{Online] Available: http://www.thecrimson.com/article/1969/5/7/giuseppe-ungarettipthe-century-has-been/?page=1

Finzi, Gilberto.(2005). "Salvatore Quasimodo dhe Poetika e fjalës", Introduction to Një hark i hapur, Tirana: Ombra GVG.

Frisardi, Andrew. (2002). "Giuseppe Ungaretti and the Image of Desolation." The Hudson Review LV, No. 1. pp. 75-89. 
Hamiti Sabri. (2003). "Zef Zorba" in Studime letrare. Prishtinë: ASHAK.

Jones, Frederic Joseph. (1977). "Personal Aesthetics and Cultural Perspectives." In Giuseppe Ungaretti: Poet and Critic, pp. 23-59. Edinburgh: Edinburgh University Press.

Kadare, Ismail. (2010). Introduction in Zef Zorba, Buzë të ngrira në gaz. Tiranë: Botime Princ.

Kuçuku, Bashkim.(2012). Modernizmi në poezinë bashkëkohore. Tiranë: Manuscript.

Lanksch, H.J. (1992) "Zef Zorba, një hermetist shqiptar". [Online] Available: http://zefzorba.blogspot.com/2008/12/zef-zorba-njihermetist-shqiptar.html.

Mandelbaum, Allen. (1975). Preface to Selected Poems of Giuseppe Ungaretti,translated and edited by Allen Mandelbaum, pp. ix-xvi. Ithaca, New York: Cornell University Press.

Ndreca, Ardian. (2010). "Letërsia në pritje të poetit". [Online] Available: http://www.shqiperia.com/Letersia-ne-pritje-te-poetit.6637/.

Sinani, Shaban. (2011). Letërsia në totalitarizëm dhe Dossier K. Tiranë: Botime Naimi.

Ungaretti Giuseppe. (2009). Vita d'un uomo; 106 poesie 1914-1960. Milano: Oscar Mondadori.

Xhiku, Ali. (2014). "Një pasqyrë e Shqipërisë letrare në vitet 194-1961". Tiranë: Manuscript.

Zorba Zef. (2010). Buzë të ngrira në gaz. Tiranë: Botime Princ. 
ISSN 2239-978X

ISSN 2240-0524
Journal of Educational and Social Research MCSER Publishing, Rome-Italy
Vol. 4 No. 6 September 2014 